\title{
The Role of Transhumance on Land Use/Cover Changes in Mountain Vermio, Northern Greece: A GIS Based Approach
}

\author{
Paraskevi SKLAVOU ${ }^{1}$, Maria KARATASSIOU ${ }^{2 *}$, Zoi PARISSI ${ }^{1}$, \\ Georgia GALIDAKI ${ }^{3}$, Athanasios RAGKOS ${ }^{4}$, Anna SIDIROPOULOU ${ }^{2}$
}

\author{
${ }^{1}$ Aristotle University of Thessaloniki, Department of Forestry and Natural Environment, Laboratory of Range Science, P.O. Box 236, 54124 \\ Thessaloniki,Greece; psklavou@for.auth.gr;pz@for.auth.gr \\ ${ }^{2}$ Aristotle University of Thessaloniki, Department of Forestry and Natural Environment, Laboratory of Rangeland Ecology, P.O. Box 286, \\ 54124 Thessaloniki, Greece; karatass@for.auth.gr (*correspondingauthor); asidir77@for.auth.gr \\ ${ }^{3}$ Aristotle University of Thessaloniki, Department of Forestry and Natural Environment, Laboratory of Forest Management and Remote Sensing, \\ P.O.Box 248, 54124 Thessaloniki, Greece; galidaki@for.auth.gr \\ ${ }^{4}$ Agricultural Economics Research Institute, ELGO Demeter, Terma Alkmanos str.115 28, Athens, Greece; ragkos@agreri.gr
}

\begin{abstract}
Transhumant flocks graze the vegetation of medium and high elevation rangelands during late spring to autumn depending on the geographical area and climatic conditions. This study aimed to assess and interpret the impacts of transhumance decline on the land use/cover on Mountain Vermio, for the period 1985-2009. For many years, this area has received high stocking rates from transhumant livestock. However, during the last 30 years transhumance has been dramatically decreased. Land cover changes have been identified using a post classification comparison approach within a Geographical Information Systems environment. Moreover, the rate and the spatial differentiation of land use/cover were determined by means of the Dynamic Degree Index. According to the results, the acreage of grasslands and grazed open forests has decreased during the study period (3\% and $83 \%$ respectively), while shrublands demonstrated an opposite trend with an increase of $25 \%$. Furthermore, based on the Dynamic Degree Index, the greatest changes occurred in the conversion of grazed open forests and shrublands, compared to other land use/cover categories. This can be attributed to changes in sheep and goats populations grazing in the area, also related to the dispersion of flocks in local rangelands. Moreover, this article presents the results of a questionnaire survey on transhumant herders. These results, combined with the assessment of changes in the Dynamic Degree Index, reflect the difficulties that farmers face in terms of access to rangelands and their increased awareness regarding the environmental role of transhumance.
\end{abstract}

Keywords: dynamic degree index, spatio-temporal changes, extensive systems, encroachment, grazing, small ruminants Abbreviations: Dynamic Degree Index (DDI); Geographical Information Systems (GIS)

\section{Introduction}

Transhumance is a common practice of seasonal movement of livestock between two specific areas repeated each year (Nyssen et al., 2009) in order to cope with the seasonality of grazing in Mediterranean areas (Galanopoulos et al., 2011). The system is still alive in most countries of the Mediterranean basin, maintained mainly by flocks of small ruminants (Ispikoudis et al., 2004; Hadjigeorgiou, 2011; Pardini and Nori, 2011; Thevenin, 2011). Additionally, the transhumant sheep and goats livestock system has a dynamic character, which is been manifested through its social, economic and environmental impact in the areas involved (Ragkos et al., 2015). Transhumant flocks graze in mountainous rangelands and thus provide a variety of ecosystem services (Bernués et al., 2011), while they contribute especially to maintaining biodiversity in fragile ecosystems, as well as the diversity of local ruminant breeds. The system also constitutes a particularly suitable activity for the development of less-favoured areas (Laga et al., 2012) especially in terms of production of high quality typical products. It also contributes to the establishment of cultural linkages among winter and summer residences. Elements of agricultural cultural heritage are currently recognized as intangible cultural heritage and efforts are made throughout the Mediterranean to inscribe transhumance in UNESCO 
590

catalogues. Similar husbandry systems have been reported in countries of Central Europe (Luick, 2004; Wolff and Fabre, 2004) and Northern Europe (Jordal, 2004; Eriksson, 2011).

Despite its numerous contributions, sheep and goat transhumance in Greece, as well as in many Mediterranean countries (Oteros-Rozas et al., 2013) has presented a decreasing trend during the last 30 years. Nowadays, according to the Greek Payment and Control Agency for Guidance and Guarantee Community Aid (PCAGGCA, 2011) there are about one million transhumant small ruminants' heads. On the contrary, according to Chatzimichali (2007) around 1960, there were about two million transhumant sheep and goats. Transhumant flocks actually use the natural vegetation of intermediate and high elevation rangelands from late spring to autumn (4-6 months) (Zervas, 1998) to graze the lush forage that grows on these areas. The perceptions and livelihood of people poses differential utilization of natural resources, facilitating general ecosystem and vegetation changes, as well as land use/cover change (Wondie et al., 2011; Aryal et al., 2014). Thus, the decline of transhumance and the subsequent decrease in the utilization of mountainous rangelands drive these areas towards late successional stages, and consequently shrub encroachment, decrease of available forage production, and modification of biodiversity and landscape (O'Flanagan et al., 2011; Oteros-Rozas et al., 2013). Hence, the identification of the conversion in vegetation types and the land use/cover changes is necessary in order to understand the multi temporal dynamics of the ecosystems.

Landscapes as maquis, dehesas, montados has been formed under grazing pressure (Gómez Sal and Lorente, 2004) and the transhumance has an important role in this landscape shaping (Gómez Sal, 2000; Sklavou et al., 2014). Recently remote sensing and Geographical Information Systems (GIS) applications have been reported for the analysis and quantification of spatio-temporal land use /cover dynamics, worldwide e.g. in China (Li et al., 2003; Quan et al., 2006; Peng et al., 2008; Zhoo et al., 2008; Deng et al., 2009; Liu et al., 2010; Wang et al., 2014; Gao et al., 2015), Italy (Salvati et al., 2012), Ethiophia (Wondie et al., 2011; Belay et al., 2015), and Greece (Ispikoudis and Houvardas, 2005; Sidiropoulou et al., 2015).

Moreover, the Dynamic degree Index (DDI) (Liu and Buhe, 2000; Li et al., 2003; Chunxiao et al., 2008) which refers to the conversion rate of a land use/cover category to another during a certain period, has been used to quantify the changes of land use/cover. However, in Greece there is limited research concerning the conversion rate of a land use/cover change expressed by DDI, although this index is sufficient to represent all land use changes.

Mount Vermio is one of the mountainous areas that for many years have received high stocking rates during late spring and summer, from transhumant sheep and goats flocks especially from Thessaly (Central Greece) (Sidiropoulou et al., 2015). In the 1950s there were about 200,000 sheep and goats grazing in the study area (Chatzimichali, 2007), but over the last decades this pressure seems to be reduced. Indeed, although 225,000 transhumant small ruminants were reported in 1957 (Chatzimichali, 2007) nowadays only 27,000 heads
(PCAGGCA, 2011) graze in the area (Sklavou et al., 2014). An ethnic group named "Sarakatsanoi" mainly used the whole area as summer grazing rangelands for their flocks. Sarakatsanoi had established a particular form of social organization called "Tseligata", within which a number of small-scale transhumant families would unite and collaborate. In the past, 27 Tseligkata were located in the area, the majority of which established in altitude zones of approximately $1,500 \mathrm{~m}$, with the lowest being at $1,100 \mathrm{~m}$ (Sklavou et al., 2014; Sidiropoulou et al., 2015). Today, only seven Tseligkata exist in Mount Vermio (Sklavou et al., 2014) following the same trend as the number of transhumant animals and farms.

This study aimed to record the spatio-temporal land use/cover changes, in Mount Vermio, Northern Greece using spatial orientation analysis of GIS. The specific objectives of this study were: a) To evaluate the land use /cover changes of Mount Vermio for 1985 and 2009, b) To estimate the characteristics of land use/cover changes using a DDI between 1985 and 2009, in order to evaluate the effects of transhumance decline, and c) To assess and interpret the impact of transhumance decline on the land use/cover changes.

\section{Materials and Methods}

\section{Description of the study site}

The study was conducted in Mount Vermio, which is located at the Regional Units of Pella, Imathia and Kozani in Northern Greece. The survey has covered an area of 94,406 ha in an altitude range between $700 \mathrm{~m}$ to $2,065 \mathrm{~m}$ a.s.l.

The areas with high altitudes of Mount Vermio (above $1,500 \mathrm{~m})$, according to classification of Emberger et al. (1963) belong to the sub-Mediterranean zone, while the lower ones belong to the meso-Mediterranean zone (Mavromatis, 1978). The mean annual precipitation is approximately $699.83 \mathrm{~mm}$ and the mean annual air temperature is $15^{\circ} \mathrm{C}$. The main land covers in the study area are forests and rangelands (which differentiate in grasslands, shrublands and grazed open forests). Forests and shrublands are dominated by plant species such as Pinus nigra Arn., Abies borisii-regis Mattf., Castanea sativa Miller., Quercus sp., Salix sp., Populus sp., Platanus sp, Acer sp., Ilex aquifolium L., Juniperus sp., Fraxinus sp., Buxus sempervirens L., Cornus sp., and Prunus sp. (Zianis and Mencuccini, 2003). The rangelands in the lowlands are grazed by ruminants and in the upper land are mainly grazed by transhumant sheep and goats from Thessaly (Sidiropoulou et al., 2015).

\section{Data sources and land use/cover classification system}

Land cover information for 1985 was extracted by the map of Forest Vegetation and Land Cover by the Ministry of Productive Reconstruction, Environment and Energy (Former Ministry of Rural Development) (year of publication 1986-1987). The land use/cover categories of this map were indicative of the classification scheme designed and they were merged to a six land cover categorization scheme to suit the purposes of this study (Table 1). 
Land cover information for 2009 was collected through photointerpretation and digitization on a true colour orthomosaic of the National Cadastre Agency, with spatial resolution of $0.5 \mathrm{~m}$ and scale of 1:5,000. Altitude stratification of the land cover changes was based on the ASTER GDEM V2 digital elevation model, which was generated using stereo-pair images collected by the ASTER instrument onboard Terra Satellite, and is freely distributed by NASA.

For the land cover change detection the post classification comparison approach was implemented, within a GIS environment. The two maps 1985 and 2009 were combined through their intersection, which resulted in a polygon layer that preserved all the boundaries found in the two original layers. This way, each polygon in the new layer carries information of the land cover of each time, therefore change information can be extracted and further analysed. This layer was combined with the digital elevation model, in order to address land cover changes in different elevation zones. The study area was divided into four elevation zones, namely 700-800 m, 800-1,200 m, 1,200$1,500 \mathrm{~m}$, and $1,500-2,000 \mathrm{~m}$. Nowadays, in the first two zones, ruminants reared under extensive husbandry systems graze alongside with transhumant flocks (PCAGGCA, 2011). Moreover, in the other two zones only transhumant flocks graze.

Finally, a map with the following four land use/cover change types was produced: a) woody species encroachment: where there was a change from open to more dense vegetation cover consisting of: grasslands (G)/ grazed open forests (GOF)/shrublands (S)/ forests (F), b) thinning: where there was a change from dense to less dense/open vegetation cover consisting of: Forests (F)/ shrublands (S) / grazed open forests (GOF)/ grasslands (G), c) no change and, d) change to other use (none of the above).

\section{Dynamic degree of land use/cover}

The spatial differences of land use/cover changes rate were represented by the dynamic degree index. The dynamic degree index was calculated by a simple formula as follows (Liu and Buhe, 2000; Li et al., 2003; Liu et al., 2003):

$$
S=\left[\sum_{i, j}^{n}\left(\frac{\Delta S_{i-j}}{S_{i}}\right) \cdot\left(\frac{1}{t}\right) \cdot 100 \%\right] \quad(i, j=1,2, \ldots n)
$$

Where: $S$ is the land use change rate, $S_{i}$ is the area of the initial land use category $i$, at the beginning of the study period, $\Delta S_{i j}$ is the overall area of land use category $i$ changed to $j$ at the time of scale of $t$ (24 years). When we set $t$ as year, the $S$ represented annual change rate of a certain type of land use in the study area (Chunxiao et al., 2008).

\section{Results and Discussion}

\section{The change of the land use/cover}

According to the results reported in Table 2, there was a significant differentiation in the land use/cover in Mount Vermio for the period 1985 to 2009. Rangelands accounted for $59.1 \%$ and $55.6 \%$ of the study area, in 1985 and 2009 respectively (Table 2), while all other covers, including forests, agricultural lands and other areas represented in total $40.8 \%$ and $44.4 \%$ respectively.

Concerning rangelands, grasslands and grazed open forests they were decreased by $3 \%$ and $83 \%$ respectively, while shrublands had a different trend with an increase of 25\% (Fig. 1). The category "other areas" exhibited an overall increase of $142 \%$, due to the establishment of a mining field in the south-western part of the study area.

Throughout the period of 24 years (1985-2009), land use/cover were diversified. Among the increased land uses, shrublands contributed by $42.6 \%$ and forests by $16.7 \%$ (Fig. 2). These increases were probably due to the gradual decline of transhumance grazing in the study area that leads to higher encroachment (Spatz and Papachristou, 1999). More specifically, the substantially decreased population of small ruminants grazing in the area, which represent only $10 \%$ of those grazing during the 50 s, is very low to exploit the whole area. The decrease of grazing pressure has led to shrub encroachment, which was been intensified by the reduction of grazed open forests by $76.6 \%$ and grasslands by $18.6 \%$ (Fig. 2). Moreover, the decrease of local populations and the decline in logging contributed to the reduction in grazed open forests. Furthermore, a decrease of $4.8 \%$ in agricultural lands was recorded which is probably due to increase of abandoned fields.

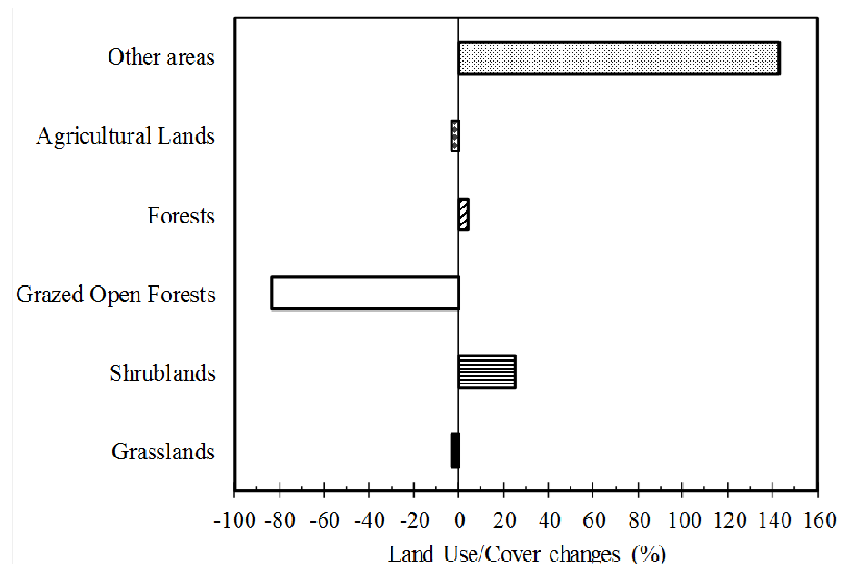

Fig. 1. Land use/cover changes (\%) of Mount Vermio in the period 1985-2009

Table 1. Land use/cover categories used in the classification scheme

\begin{tabular}{cc}
\hline Land use / cover & Characterization features \\
\hline Grasslands & Areas dominated by herbaceous plants, with ground cover of woody vegetation less than $10 \%$ \\
Grazed Open Forests & Areas dominate by herbaceous plants, with ground cover of woody vegetation between $10 \%$ and $40 \%$ \\
Shrublands & Areas dominated by evergreen woody shrubs with sclerophyllous leaves \\
Forests & Areas with relative tree cover higher than $40 \%$ \\
Agricultural lands & Fields with permanent or temporary crops \\
Other Areas & Areas with manmade features, including villages, mining fields etc. \\
\hline
\end{tabular}


592

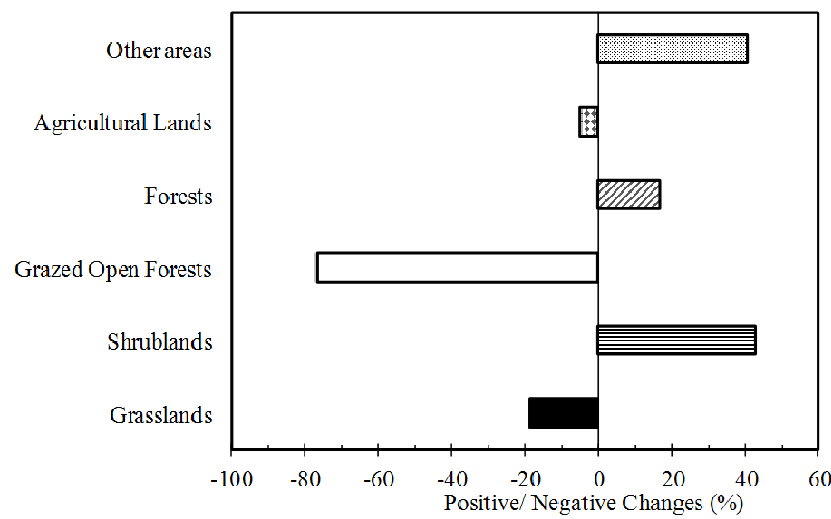

Fig. 2. Land use /cover changes (positive and negative) (\%) in Mount Vermio in the period 1985-2009

The dynamic degree and the conversions of land use/cover

The values of the dynamic degree index for grazed open forests and shrublands were obviously higher than that of other land use categories (Table 3). Grazed open forests and shrublands with dynamic degree $3.969 \%$ and $2.216 \%$ respectively suggested higher changes of land use cover. The cause of higher value of dynamic degree of grazed open forests was that their total area was the smaller between all types (Table 2). The main reason for that probably lies on the gradual reduction of grazing pressure of transhumant flocks, which has led to woody species encroachment. Moreover, this finding is in line with what Kerckhof $e t a l$. (2016) reported for 14 rural Montenegrin settlements. According to Kyriazopoulos et al. (2012) the expansion of shrub species could affect biodiversity as well as socioeconomic values, goods and services provided by grasslands (Camarero et al. 2015).

Additionally, the high value of the DDI for shrublands was probably due to selective abandonment of tree-line grazing. As the number of animals decreased, the remaining animals covered their requirements in more accessible areas of lower altitude. Kyriazopoulos et al. (2017) have reported similar results, especially for the Pindos Mountain treeline ecotones, where Juniperus spp. encroachment has been witnessed in formerly grazed rangelands. In the last decades, there is an upward increase of treelines as anthropogenic activities have been decreased (Ameztegui et al., 2016; Kyriazopoulos et al., 2017).

Agricultural lands and other areas have relatively similar values of the dynamic degree index $(1.345 \%$ and $1.498 \%$ respectively) (Table 3). The higher value of DDI for other lands was due to the fact that the total area was smaller in relation to agricultural lands. The change of the dynamic degree for grasslands was similar to the one for forests. These values of dynamic degree near $1 \%$ indicate high changes on grasslands and forests as well (Chunxiao et al., 2008). Probably, both of them have been affected more by the transhumance decline, as the ecological role of grazing has stopped via secondary succession (Papanastasis, 2009) and the positive pressure of grazing has been limited (Potthoff, 2009).

Through the study period, the conversion of land use/cover could be probed into. About $60 \%$ of the changed grasslands converted to shrublands, grazed open forests and forests (Table 3). The $75 \%$ of changed forests converted to grazed open forests and shrublands.
Table 2. Land use/cover (ha) in Mount Vermio, Northern Greece in 1985 and 2009

\begin{tabular}{ccc}
\hline \multirow{2}{*}{ Land use/cover categories } & \multicolumn{2}{c}{ Years } \\
\cline { 2 - 3 } & $39,152.40$ & $37,956.03$ \\
\hline Grasslands & $5,912.34$ & $1,002.14$ \\
Grazed open forests & $10,775.62$ & $13,512.80$ \\
Shrublands & $27,440.63$ & $28,509.27$ \\
Forests & $9,296.47$ & $8,984.61$ \\
Agricultural lands & $1,829.97$ & $4,441.58$ \\
\hline Other areas & $94,406.43$ & $94,406.43$ \\
\hline Total & & \\
\hline
\end{tabular}

\section{The elevation differentiation of land use/cover}

In order to obtain better understanding of land use/cover changes from 1985 to 2009 through transhumance decline it is useful to examine them in relation to the elevation zone where they occurred (Fig. 3). In the $1^{\text {st }}$ zone $(700-800 \mathrm{~m})$ which occupied the $16.25 \%$ of the total area, the land use / cover changes from dense to less dense/ open vegetation cover contributed by $10.3 \%$. Additionally, in the $2^{\text {nd }}$ zone $(800-1,200 \mathrm{~m})$ woody species encroachment occupied $13.8 \%$, while the opposite trajectory change to less dense or open vegetation cover occupied 15.2\%.

Similarly, changes were observed on $3^{\text {rd }}$ zone $(1,200-$ $1,500 \mathrm{~m})$ where the higher percentage $(13.9 \%)$ of woody species encroachment was presented, while the total thinning of forest to shrubland, to grazed open forest and grassland occupied $10.1 \%$. On the $4^{\text {th }}$ zone $(>1,500 \mathrm{~m})$ which occupied $18.5 \%$ of the total area the percentage of woody species encroachment was the highest compared to the other changes $(9.6 \%)$.

As it is obvious on second and third zone which occupied the $65 \%$ of the total area the higher land use / cover changes referring to woody species encroachment and thinning were observed. This is probably due to different spatial grazing pressure, decreased stocking rate from transhumant flocks, as well as the herder's selection of grazing lands. A number of factors in mountainous Mediterranean areas affect in different ways land use/cover changes (Kerckhof et al., 2016).

The dynamic degree index in the four zones followed the same trend (Table 4) as that of the total study area (Table 3). The DDI for grasslands and forests on $1^{\text {st }}$ and $2^{\text {nd }}$ zone (700-800 $\mathrm{m}$ and $800-1,200 \mathrm{~m}$ ) were greater than that of upper zones $(1,200-1,500 \mathrm{~m}$ and $>1,500 \mathrm{~m})$. Moreover, grazed open forests and shrublands had the highest value of DDI on all elevation zones. These results indicate a high land use/cover change due to the decrease of anthropogenic activities as transhumance. These findings are in agreement with other studies in mountainous areas (Palombo et al., 2013; Ainalis et al., 2015).

\section{Economic implications in the study area}

The vulnerability of local farms to land use changes can be seen in the Table 5, where economic performance indicators of local farms are reported. The primary data were gathered through a small-scale questionnaire survey of 7 farms, which rear about $35 \%$ of the total animals grazing in Mount Vermio during summer. On average farms rear about 600 sheep and 94 goats which achieve relatively low 
Table 3. The Dynamic Degree Index (DDI, \%) and the conversions of land use / cover (ha) in Mount Vermio in the period 1985-2009

\begin{tabular}{|c|c|c|c|c|c|c|c|c|}
\hline & $\mathrm{G}^{*}$ & GOF & $S$ & $\mathrm{~F}$ & $\overline{\mathrm{AL}}$ & $\overline{\mathrm{OA}}$ & Changed Area & DDI \\
\hline G & 0.00 & 350.35 & 1831.82 & 2387.95 & 1873.81 & 1075.72 & 7519.65 & 0.800 \\
\hline GOF & 780.13 & 0.00 & 2188.85 & 2559.82 & 80.51 & 23.67 & 5632.98 & 3.969 \\
\hline S & 3351.16 & 119.44 & 0.00 & 2024.46 & 139.10 & 98.22 & 5732.38 & 2.216 \\
\hline $\mathrm{F}$ & 1277.29 & 231.17 & 4299.90 & 0.00 & 183.07 & 87.97 & 6079.40 & 0.923 \\
\hline $\mathrm{AL}$ & 770.81 & 14.50 & 132.06 & 99.40 & 0.00 & 1984.69 & 3001.46 & 1.345 \\
\hline OA & 143.88 & 7.34 & 16.91 & 76.42 & 413.11 & 0.00 & 657.66 & 1.498 \\
\hline Total & 6323.27 & 722.80 & 8469.54 & 7148.05 & 2689.60 & 3270.27 & 28623.53 & \\
\hline
\end{tabular}

Table 4. The Dynamic Degree Index (\%) in four elevation zones in Mount Vermio in the period 1985-2009

\begin{tabular}{|c|c|c|c|c|c|c|}
\hline Elevation Zones & $\mathrm{G}^{*}$ & GOF & $S$ & $\bar{F}$ & $\mathrm{AL}$ & $\mathrm{OA}$ \\
\hline $700-800 \mathrm{~m}$ & 1.952 & 4.126 & 2.399 & 1.750 & 1.225 & 1.395 \\
\hline $800-1,200 \mathrm{~m}$ & 1.110 & 4.025 & 2.015 & 1.187 & 1.538 & 1.417 \\
\hline $1,200-1,500 \mathrm{~m}$ & 0.724 & 3.861 & 2.733 & 0.582 & 1.248 & 2.196 \\
\hline $1,500-2,000 \mathrm{~m}$ & 0.319 & 4.011 & 1.433 & 0.443 & 3.117 & 2.645 \\
\hline
\end{tabular}

${ }^{*} \mathrm{G}=$ Grasslands, GOF= Grazed Open Forests, $\mathrm{S}=$ Shrublands, $\mathrm{F}=$ Forests, $\mathrm{AL}=$ Agricultural Lands, OA=Other Areas

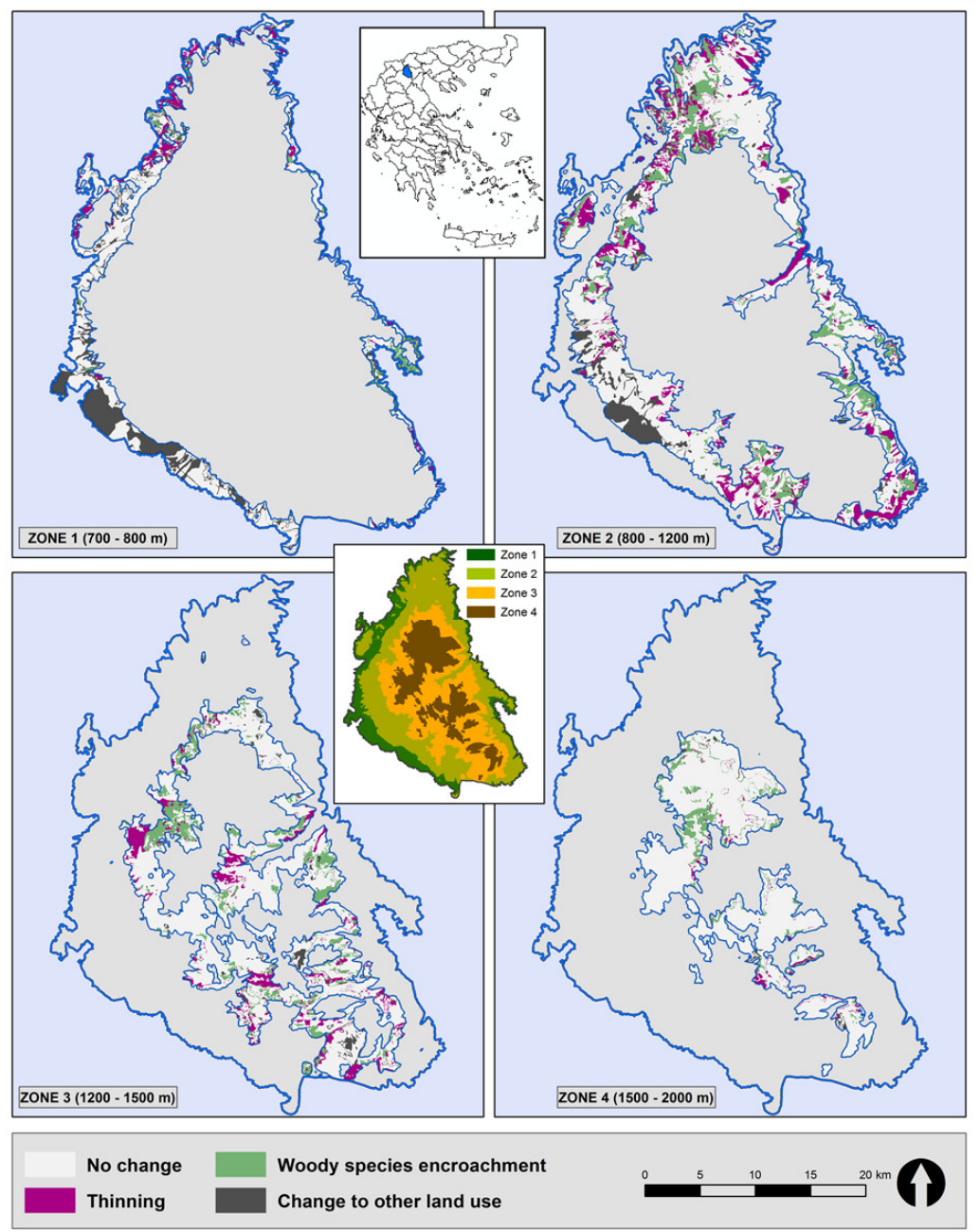

Fig. 3. Land use / cover changes in four elevation zones in Mount Vermio in 1985 and 2009

milk yields ( $92.6 \mathrm{~kg} /$ ewe and $94.5 \mathrm{~kg} /$ dam respectively). Nonetheless, this drawback is more than counterbalanced by the low expenses that transhumance incurs. As can be seen, total expenses are $163.1 € /$ ewe $($ dam $)$ of which $47 \%$ stand for feeding expenses $(47 € /$ ewe $(\mathrm{dam}))$ during the winter period spent in the lowlands. Ragkos et al. (2014) reported that the total feeding expenses for transhumant farms in Thessaly Central Greece were higher (73.7 $€ /$ ewe/dam) while in intensive systems feeding costs ranged between 157 and $182 € /$ ewe (Roustemis, 2012). Hence, the financial results of transhumant farms in the study area are quite satisfactory (Table 5). Therefore, the utilization of 
594

Table 5. Technical and economic indicators, production expenses and financial results of transhumant farms in Mount Vermio

\begin{tabular}{|c|c|c|}
\hline Indicator & Ewes & Dams \\
\hline Flock size & 599.2 & 94.5 \\
\hline Average milk yield & $\begin{array}{c}92.6 \\
\mathrm{~kg} / \mathrm{ewe}\end{array}$ & $\begin{array}{c}85.4 \\
\mathrm{~kg} / \mathrm{dam}\end{array}$ \\
\hline Labor requirements & \multicolumn{2}{|c|}{$12.1 \mathrm{~h} /$ ewe (dam) } \\
\hline Farm expenses & $\begin{array}{l}€ / \text { ewe } \\
(\text { dam })\end{array}$ & $\%$ \\
\hline Land rent & 4.7 & 2.9 \\
\hline Labor costs & 40.9 & 25.1 \\
\hline Capital costs & 117.5 & 72.0 \\
\hline Variable capital & 96.0 & 58.9 \\
\hline Purchased feedstuff & 73.5 & 45.1 \\
\hline Animal production variable costs & 19.2 & 11.8 \\
\hline Crop production (for feedstuff) & 3.3 & 2.1 \\
\hline Fixed capital & 21.5 & 13.2 \\
\hline TOTAL FARM EXPENSES & 163.1 & 100 \\
\hline $\begin{array}{c}\text { Gross output per product (source) } \\
(€ / \text { ewe (dam)) }\end{array}$ & 183.4 & 100 \\
\hline Milk & 101.4 & 55.4 \\
\hline Cheese/Wool & 5.5 & 3.0 \\
\hline Meat & 51.2 & 27.9 \\
\hline Income support (subsidies) & 25.1 & 13.7 \\
\hline \multicolumn{3}{|l|}{$\begin{array}{c}\text { Financial results } \\
(€ / \text { ewe }(\text { dam }))\end{array}$} \\
\hline Net profit & \multicolumn{2}{|c|}{20.2} \\
\hline Labor wage $(€ / \mathrm{h})$ & \multicolumn{2}{|c|}{5.05} \\
\hline Farm Income & \multicolumn{2}{|c|}{79.9} \\
\hline Gross profit & \multicolumn{2}{|c|}{87.3} \\
\hline
\end{tabular}

local natural rangelands is the main source of flexibility of these farms and largely defines their viability. The land use/cover changes pointed out through the calculation of the DDI demonstrate that the danger of encroachment and the expansion of shrublands can threaten the economic performance of farms, as this phenomenon would reduce the availability of grazing material, therefore pointing towards the need for more purchased feedstuff.

\section{Conclusions}

Transhumance decline is the main driving force of land use/cover changes in the study area of Mountain Vermio. During a 24-year period the major changes of land use/cover in Mount Vermio concerned grazed open forests and shrublands. These changes not only have important environmental implications but also affect the potential of the transhumance system. The main land use substitution dynamics that occurred in the area due to the constant decrease of the grazing pressure have been revealed through the calculation of the dynamic degree. Therefore, was found that human activities - even in terms of semi-extensive practices - not only affect the natural environment, but were also the cause of changes, which affected the dynamics and future prospects of these activities themselves. In addition, the study of land use/cover changes is imperative for the coming years in order to maintain transhumance system in the region of Mount Vermio in Northern Greece.

\section{Acknowledgements}

This paper is part of the project "The dynamics of the transhumant sheep and goat farming system in Greece. Influences on biodiversity" which is co-funded by the European Union (European Social Fund) through the Action "THALIS".

\section{References}

Ainalis A, Meliadis I, Tsiouvaras K, Ainali K, Platis D, Platis P (2015). Multitemporal land use changes in a region of Pindus mountain, central Greece. Agricultural Forestry and Fisheries 4:18-23.

Ameztegui A, Coll L, Brotons L, Ninot JM (2016). Land-use legacies rather than climate change are driving the recent upward shift of the mountain treeline in the Pyrenees. Global Ecology and Biogeography 25:263-273.

Aryal S, Cockfield G, Maraseni TN (2014). Vulnerability of Himalayan transhumant communities to climate change. Climatic Change 125(2):193-208.

Belay KT, Van Rompaey A, Poesen J, Van Bruyssel S, Deckers J, Amare $\mathrm{K}$ (2015). Spatial analysis of land cover changes in Eastern Tigray (Ethiopia) from 1965 to 2007: Are there signs of a forest transition?. Land Degradation and Development 26(7):680-689.

Bernués A, Ruiz R, Olaizola A, Villalba D, Casasús I (2011). Sustainability of pasture based livestock farming systems in the European Mediterranean context: synergies and trade-offs. Livestock Science 139:4457.

Camarero JJ, Garcia-Ruiz JM, Sangüesa-Barreda G, Galvàn JD, Alla $A Q$, Sanjuàn Y, Beguerìa S, Gutièrrez E (2015). Recent and intense dynamics in a formerly static Pyrenean treeline. Arctic, Antarctic, and Alpine Research 47:773-783.

Chatzimichali A (2007). Sarakatsanoi (in Greek). Angeliki Chatzimichali Foundation $\left(2^{\text {nd }} \mathrm{Ed}\right)$, Athina, Greece.

Chunxiao Z, Zhiming L, Nan Z (2008). Using remote sensing and GIS to investigate land use dynamic change in western plain of Jilin province. The International Archives of the Photogrammetry. Remote Sensing and Spatial Information Science 37:1685-1690.

Deng JS, Wang K, Hong Y, Qi JG (2009). Spatio-temporal dynamics and evolution of land use change and landscape pattern in response to rapid urbanization. Landscape and Urban Planning 92(3):187198.

Emberger L, Gaussen H, Kassas M, dePhilippis A (1963). Bioclimatic map of the Mediterranean zone, Ecological study of the Mediterranean zone, explanatory notes. Arid Zone Research 21. UNESCO-FAO, Paris.

Eriksson C (2011). What is traditional pastoral farming? The politics of heritage and 'real values' in Swedish summer farms (fäbodbruk). Pastoralism: Research, Policy and Practice 1(25):1-18.

Galanopoulos K, Abas Z, Laga V, Hatziminaoglou I, Boyazoglu J (2011). The technical efficiency of transhumance sheep and goat farms and the effect of EU subsidies: Do small farms benefit more than large farms? Small Ruminant Research 100(1):1-7.

Gao P, Niu X, Wang B, Zheng Y (2015). Land use changes and its driving forces in hilly ecological restoration area based on GIS and RS of Northern China. Scientific Reports 5:1-11. 
Gómez Sal A (2000). The variability of Mediterranean climate as an ecological condition of livestock production systems. In Livestock production and climatic uncertainty in the Mediterranean. Proceedings of the joint ANPA-EAAP-CIHEAM-FAO symposium. Agadir, Morocco: WageningenPers pp 3-11.

Gómez Sal A, Lorente I (2004). The present status and ecological consequences of transhumance in Spain. In: Bunce RGH, PérezSoba M, Jongman RHG, Gómez Sal A, Herzog F, Austad I (Eds). Transhumance and Biodiversity in European Mountains. Alterra, Wageningen pp 233-248.

Hadjigeorgiou I (2011). Past, present and future of pastoralism in Greece. Pastoralism: Research, Policy and Practice 1(24):1-22.

Ispikoudis I, Chouvardas D (2005). Livestock, land use and landscape. In: Georgoudis A, Rasati A, Mosconi C (Eds). Animal production and natural resources utilisation in the Mediterranean mountain areas. Wageningen, Academic Publishers, European Association For Animal Production (EAAP) Scientific Series No 115 pp 151157.

Ispikoudis I, Sioliou M, Papanastasis V (2004). Transhumance in Greece: Past, present and future prospects. In: Bunce RGH, PérezSoba M, Jongman RHG, Gómez Sal A, Herzog F, Austad I (Eds). Transhumance and Biodiversity in European Mountains. Alterra, Wageningen pp 211-229.

Jordal JB (2004). Diversity of macrofungi in seminatural grasslands of the subalpine summerfarm landscape around Dovre, Southern Norway. In: Bunce RGH, Pérez-Soba M, Jongman RHG, Gómez Sal A, Herzog F, Austad I (Eds). Transhumance and Biodiversity in European Mountains. Alterra, Wageningen pp 31-33.

Kerckhof A, Spalevic V, Eetvelde V, Nyssen J (2016). Factors of land abandonment in mountainous Mediterranean areas: the case of Montenegrin settlements. SpringerPlus 5:485.

Kyriazopoulos AP, Abraham EM, Parissi ZM, Korakis G (2012). Woody species invasion and encroachment in rangeland ecosystems (in Greek). Scientific Annals of the Department of Forestry and Management of the Environment and Natural Resources 3(1):203216.

Kyriazopoulos AP, Skre O, Sarkki S, Wielgolaski FE, Abraham EM, Ficko A (2017). Human-environment dynamics in European treeline ecosystems: a synthesis based on the DPSIR framework. Climate Research. https://doi.org/10.3354/cr01454.

Laga V, Ragkos A, Skapetas V, Mitsopoulos I, Kiritsi S, Abas Z, ... Bambidis V (2012). Current trends in the transhumant sheep and goat sector in Greece. Options Méditerranéennes Série A 102:473476.

Li R, Liu J, Zhuang D, Wang H (2003). The spatial-temporal changes of the land use/cover in the Dongting Lake area during the last decade. Journal of Geographical Sciences 13(3):259-264.

Liu J and Buhe A (2000). Study on spatial-temporal feature of modern land-use change in China: Using remote sensing techniques. QuaternarySciences 20(3):229-239.

Liu J, Zhang Z, Xu X, Kuang W, Zhou W, Zhang S, ... Jiang N (2010). Spatial patterns and driving forces of land use change in China during the early 21st century. Journal of Geographical Sciences 20(4):483-494.
Liu JY, Liu ML, Zhuang DF ..., Deng X (2003). Study on spatial pattern of land-use change in China during 1995-2000. Science in China Series D: Earth Sciences 46(4):373-384.

Luick R (2004). Transhumance in Germany. In: Bunce R, Pérez-Soba M, Jongman R, Gómez Sal A, Herzog F, Austad I (Eds). Transhumance and Biodiversity in European Mountains. Alterra, Wageningen pp 137-154.

Mavromatis G (1978). Bioclimatic map of Greece (in Greek). Institution of Forest Research, Athens, Greece.

Nyssen J, Descheemaeker K, Zenebe A, Poesen J, Deckers J, Haile M (2009). Transhumance in the Tigray highlands (Ethiopia). Mountain Research and Development 29(3):255-264.

O'Flanagan P, Martinez T L, Errea Abad, M P (2011). Restoration of sheep transhumance in the Ebro Valley, Aragon, Spain. Geographical Review 101(4):556-575.

Oteros-Rozas E, Ontillera-Sánchez R, Sanosa P, Gómez-Baggethun E, Reyes-García V, González J (2013). Traditional ecological knowledge among transhumant pastoralists in Mediterranean Spain. Ecology and Society 18(3):33.

Palombo C, Chirici G, Marchetti M, Tognetti R (2013). Is land abandonment affecting forest dynamics at high elevation in Mediterranean mountains more than climate change? Plant Biosystems 147:1-11.

Papanastasis VP (2009). Restoration of degraded grazing lands through grazing management; can it work? Restoration Ecology 17:441-445.

Pardini A, Nori M (2011). Agro-silvo-pastoral system in Italy: integration and divestification. Pastoralism: Research, Policy and Practice 1-10.

PCAGGCA (2011). Payment and Control Agency for Guidance and Guarantee Community Aid. Registry of Farms and Farmers; Ministry of Rural Development and Food: Athens, Greece.

Peng J, Wu J, Yin H, Li Z, Chang Q, Mu T (2008). Rural land use change during 1986-2002 in Lijiang, China, based on remote sensing and GIS data. Sensors 8(12):8201-8223.

Potthoff K (2009). Grazing history affects the tree-line ecotone; a case study from Hardanger, western Norway. Fennia 187:81-98.

Quan BN, Chen JF, Qiu HL, Romkens MJM, Yang XQ, Jiang SF, Li BC (2006). Spatial-Temporal Pattern and Driving Forces of Land Use Changes in Xiamen. Pedosphere 16(4):477-488.

Ragkos A, Mitsopoulos I, Kiritsi S, Piteris C, Lymberopoulos A, Palla E, Bampidis V and Laga V (2015). Economic versus non-economic motives of transhumant farmers in Greece. Options Mediterranneens Series A 115:503-507.

Ragkos A, Siasiou A, Galanopoulos K and Laga V (2014). Mountainous grasslands sustaining traditional livestock systems: The economic performance of sheep and goat transhumance in Greece. Options Mediterraneennes 109:575-579.

Roustemis D (2012). Design of the breeding goal for Chios sheep (in Greek). Doctoral Disseration, Democritus University of Thrace, Greece.

Salvati L, Perini L, Sabbi A, Bajocco S (2012). Climate aridity and land use changes: a regional scale analysis. Geographical Research 50(2):193-203. 
596

Sidiropoulou A, Karatassiou M, Galidaki G, Sklavou P (2015). Landscape pattern changes in response to transhumance abandonment on Mountain Vermio (North Greece). Sustainability $7(11): 15652-15673$.

Sklavou P, Karatassiou M, Sidiropoulou A (2014). The role of transhumance in the evolution of vegetation and landscape: A case study in northern Greece (Vermio mountain) (in Greek). In: Proceedings of the $8^{\text {th }}$ Panhellenic Rangeland Congress on Rangelands-Livestock: Research and Development. Hellenic Rangeland Society, Thessaloniki, Greece, pp 59-64.

Spatz G, Papachristou TG (1999). Ecological strategies of shrubs invading extensified grasslands: their control and use. Grassland Science in Europe 4:27-36.

Thevenin M (2011). Kurdish Transhumance: Pastoral practices in south-east Turkey. Pastoralism: Research, Policy and Practice 1(23):1-24.

Wang, W, Guo H, Chuai X, Dai C, Lai L, Zhang M (2014). The impact of land use change on the temporospatial variations of ecosystems services value in China and an optimized land use solution. Environmental Science and Policy 44:62-72.
Wolff A, Fabre P (2004). Transhumant sheep systems of South-eastern France, with special reference to long-distance transhumance from the plain of the Crau to the Alps. In: Bunce R, Pérez-Soba M, Jongman R, Gómez Sal A, Herzog F, Austad I (Eds). Transhumance and Biodiversity in European Mountains. Alterra, Wageningen pp 113-132.

Wondie M, Schneider W, Melesse AM, Teketay D (2011). Spatial and temporal land cover changes in the Simen Mountains National Park, a world heritage site in Northwestern Ethiopia. Remote Sensing 3(4):752-766.

Zervas G (1998). Quantifying and optimizing grazing regimes in Greek mountain systems. Journal of Applied Ecology 35(6):983-986.

Zhou Q, Li B, Sun B (2008). Modelling spatio-temporal pattern of land use change using multitemporal remotely sensed imagery. The International Archives of the Photogrammetry, Remote Sensing and Spatial Information Sciences 37:729-734.

Zianis D, Mencuccini M (2003). Aboveground biomass relationships for beech (Fagus moesiaca Cz.) trees in Vermio Mountain, Northern Greece, and generalised equations for Fagus sp. Annals of Forest Science 60:439-448. 